IJLR: International Journal of Law Recontruction

Volume 5, Number 1, April 2021

DOI : http://dx.doi.org/10.26532/ijlr.v5i1.15492

\title{
IMPLEMENTATION OF PRINCIPLES IN IDENTIFYING SERVICE USERS REGARDING THE PREVENTION AND ERADICATION OF MONEY LAUNDERING OFFENSE
}

\author{
Achmad Sulchan \\ Sultan Agung Islamic University \\ ach.sulchan@unissula.ac.id \\ Ida Musofiana \\ Sultan Agung Islamic University \\ ida.musofiana@unissula.ac.id \\ A. Althof Rusydi \\ Sultan Agung Islamic University \\ adibalthofrusydi.ar@gmail.com
}

\begin{abstract}
The implementation of principles of identifying service users and suspicious financial transaction report submission for profession aims to prevent money laundering offense by postponing transaction, blocking, investigating and temporarily suspending transaction which is carried out by PPATK (Financial Transaction Reporting and Analysis Center). The method used in this study was juridical normative or legal doctrinal research, which is a legal research using secondary data conducted by emphasizing and juridical aspects. Legal-normative research is a library research, which is a research on secondary data including private documents, books, and official documents issued by government. The normative approach emphasized juridical issues regarding the legal rules on money laundering offense. The result of the study of the implementation of the principles in identifying service users regarding the prevention and eradication of money laundering offense isidentifyingservice user while having a business relationship involving suspicious financial transaction related to money laundering offense. The informant questions the validity of information provided by the service user, which necessitate the implementation of the principle of identifying the service user in carrying out banking transaction. The factors promoting the occurrence of money laundering offense in various countries consist of 9 aspects, namely: globalization, technological advancement, banks' strict secrecy policy, the possibility of saving using an alias or anonymous, the emergence of electronic money, the possibility of layering practice, the confidentiality of lawyer-client and accountant-client relationships, the government unseriousness in eradicating money laundering offense and the lack of money laundering criminalization.
\end{abstract}

Keywords: Implementation, Money Laundering, Service User, Transaction. 


\section{A. INTRODUCTION}

The emergence of various forms of evil in a new dimension recently shows that crime develops following the development of society, including criminal acts washing money or the one in English called Money Laundering. Schools are social institutions that perform the task of education to the younger generation. In this regard, education is defined as the process of humanizing towards maturation itself as well as character development. Education instilled mindset, moral values in the society which in turn transformed into the next generation to ensure survival. School as an institution in charge of transforming the cultural values of society. ${ }^{2}$ Crimes committed by the poor because of economic pressure to crime because the greed of officials who commit corruption, is still common in Indonesia. Various factors are the cause of these things such as lack of employment opportunities and low morale. ${ }^{3}$ Along with the current development, technology is getting more and more sophisticated, allowing the development of new type of crimes with international network which utilizes financial institutions, especially bank, as part of its schemes and practices. In some countries, banks are required to have and implement Service User identification policy and system to tackle money laundering offense. Besides detrimental to society, money laundering also harms the state as it can destabilize the national economy or the state finance.

Property obtained from corruption crimes usually cannot be used immediately because of the presence of fear or indications of money laundering activities. $^{4}$ Technological developments, especially in the financial sector, are getting more and more advanced developing. One of them is FinTech or Financial Technology, which is at Indonesia itself only started developing in 2007, which of course it didn't cover the possibility of money laundering and funding risks terrorism. ${ }^{5}$ Act No. 8 Of 2010 concerning Prevention and Eradication of the Crime of Washing Money has proven that it acts money laundering is a crime only threatening, stability, and integrity economic systems and systems financial, but also can endanger the joints of life social, national, and state-based on Pancasila and the Indonesian Constitution of 1945 . $^{6}$ Lately, the term 'money laundering' is quite popular in public as a result of news

1 M. Arief Amrullah, Pencegahan Tindak Pidana Pencucian Uang Melalui Jasa Gatekeeper di Indonesia, Cakrawala Hukum Journal, Volume 6, No. 1, June 2015, page. 78

2 Ida Musofiana, Anti-Corruption Education at an Early Age as a Strategic Move to Prevent Corruption in Indonesia, Proceeding The 2nd Proceeding 305, Indonesia Clean of Corruption in 2020, December 2016, page. 305.

3 Gandhung Wahyu, F.., Joko Supriyanto, Urgensi Penanggulangan Tindak Pidana Pencucian Uang Pasa Kasus Korupsi, Recidive Journal, Volume 3, No. 3, September - December 2014, p, 248.

4 Budi Bahreisy, Implementasi Undang-Undang Tindak Pidana Pencucian Uang Terhadap Kerugian, Legislasi Indonesia Journal, Volume 15, No. 2, July 2018, page. 103

5 Febrina Annisa, Prima Resi Putri, Penerapan Program Apu Ppt Untuk Mencegah Pencucian Uang Dan Pendanaan Terorisme Pada Industri Fintech, Adil Journal, Volume 11 No. 2, 2020, page. 69

6 Khairul, Mahmul Siregar, Marlina, Kewenangan PPATKDalam Pencegahan dan Pemberantasan Tindak Pidana Pencucian Uang, Mercatoria, Volume 4 No. 1, 2011, page. 33 
reports by various mass media highlighting big cases related to money laundering offense. This is of course a good social education in an effort to spread knowledge related to money laundering offense and the sizable damage it inflicts toward the national interests, as it has become the center of attention and major concern for public from different countries around the world. ${ }^{7}$

The international community has agreed to prohibit criminal offenses related to narcotics and money laundering. This agreement is stated in the United Nation Convention against Illicit Traffic in Narcotics Drugs and Psychotropic Substance of 1988, commonly known as the UN Drug Convention 1988 , which requires the members to criminalize the perpetrators of narcotics and money laundering related actions. In its development, the process involved is much more complex and it utilizes sophisticated methods in such a way that the money seems to be obtained in natural way. For this reason, The National Money Laundering Strategy for 200, which is the US's blueprint in the effort of eradicating money laundering, states that money laundering is easy to say, but very hard to investigate and prosecute. In particular, an individual who performs financial transaction with the stipulation that the fund or wealth involved in the transaction is obtained from criminal activities. ${ }^{8}$ Prevention is a process, means, action to prevent or act to prevent something from happening. It can be said that an effort made before the occurrence of a violation Eradication is a process or method of eradicating the crime of money laundering so that there is no crime that will cause the State to lose. ${ }^{9}$

Money laundering is becoming universal in nature, spreading beyond juridicial borders of different countries, which means that it is not only a national, but also regional and internationalissue. The practice of money laundering can be carried out by an individual without, say, travelling abroad. This is possible due to the advancement of information technology, by using the cyberspace system (internet), where payments can be done through bank electronically (cyberpayment). Furthermore, a perpetrator of money laundering can deposit the dirty money or hot money into a certain bank without attaching identity, which is legal in certain countries such as Austria. ${ }^{10}$

The Financial Action Task Force on Money Laundering (FATF) defines money laundering as a process of hiding or dissimulating the origin of the proceeds of crime. The process is carried out to eliminate traces which in turn allowperpetrators to enjoy the profit without disclosing the source of said profit. Illegal arms trade, smuggling, organized crimes such as drug dealing

7 Arief Amrullah, 2020, Tindak Pidana Pencucian Uang dalam Perspektif Kejahatan Terorganisasi Pencegahan dan Pemberantasannya, Kencana, Jakarta, page. 1.

8 Arif Amrullah, 2004, Tindak Pidana pencucian uang (Money Laundering), Bayumedia Publising, Malang, page. 8

9 Herlina Hanum Harahap, Pencegahan dan Pemberantasan Tindak Pidana Pencucian Uang, Amaliah Journal, Volume 4 No. 2, November 2020, page. 186.

10 N.H.T Siahaan, 2008, Money Laundering \& Kejahatan Perbankan, Jala permata, Jakarta, page. 3 
and prostitution can produce large amount of money. Embezzlement, insider trading, bribery, and computer abuse can also result in a lot of profit, which create the need to legitimize it through money laundering. Bambang Setijoprodjo, quoted Prof. Dr. M Giovanoli and Mr. J. Koers' arguments by which each wrote:

1. Money launderingis a process in which assets acquired from criminal activities are manipulated in such a way that the asset appears to have originated from a legal source.

2. Money launderingis a method of circulating the proceeds of criminal actions into a legal fund circulation and dissimulating the origin of the fund.

Furthermore, Article 1 No. 1Act No. 8 Year 2010 Regarding the Prevention and Eradication of Money Laundering Offense (State Gazette Year 2010 No. 122) states that money laundering is any action which satisfies the elements of crime in accordance with the clauses stipulated in this act. The scope of this definition is specified in the stipulations in the Act No. 8 of $2010 .^{11}$

Whilst, in Article 641 of the Bill regarding Criminal Code of 1999-2000, it is stated that: "every individual who saves money in bank or other places, transfers, leaves, grants, moves, invests, pays using money or valuable documents which is known or suspected to be obtained from narcotics or psychotropic crimes, economic and financial crimes, or corruption offense, "In the elaboration, in essence it is stated that the stipulations in article 641 is commonly known with the term money laundering. However, the stipulation is further elaborated in the Bill regarding Criminal Code of 2008, as stipulated in article 734 until 737. Similarly, in the Bill regarding Criminal Code of 2019, money laundering is also regulated in the fourth part regarding money laundering offense from article 607 until $609 .{ }^{12}$

According to the statistics published by IMF, proceeds of crime laundered through bank is estimated to be nearly US $\$ 1.500$ billion per year. Meanwhile, according to Associated Press, the majority of laundering activity of the proceeds of narcotics trade, prostitution, corruption, and other crimes are processed through banking services in order to later be converted into legal funds, and it is estimated that these activities are able to absorb US\$ 600 billion annually. This is equivalent to $5 \%$ of the GDP of the world. However, Michael Camdessus (IMF Managing Director) estimates that the volume of cross border money laundering is between $2 \%$ and $5 \%$ of the global Gross Domestic Product (GDP). In fact, the based on the lower limit of the estimation, the sum of money generated from narcotics trafficking, arm trafficking, bank fraud, securities fraud, counterfeiting, and similar crimes laundered around the world nearly reach US\$ 600 billion. ${ }^{13}$

11 Arief Amrullah, 2020, Op. Cit, page. 8-9

12 Ibid, page. 9-10

13 US Government, 2000, Secreatary of The Treasury dan Attorney General, The National Money Laundering Strategy, page. 6-7 
From the prevention standpoints, the eradication of money laundering is not only by increasing the penalty towards the perpetrators of Corruption Offense who use the proceeds for other purposes. In other words, apart from the Corruption Offense Act, there is also so-called Money Laundering Offense Act, which is meant to break a link in the chain of crimes. The severance of the criminal chain is not only executedby uncovering the crime itself, but also by cutting of the funder of the crime itself. That is why, there needs to be a criminalization or an effort to makea certain criminal act. In this case, the criminalization is carried out towards the utilization, use, and funding of activities and so on of wealth or assets related to or originated from criminal actions or obtained illegally, which is later known as money laundering offense. ${ }^{14}$

\section{B. RESEARCH METHODS}

The method used in this study was juridical normative or legal doctrinal research, This type of legal research is carried out juridically normative is juridical normative where the law is conceptualized as what is written in the laws and regulations or Law in books or law is conceptualized as a rule or norm which is a perceived benchmark for human behavior appropriate. ${ }^{15}$ This normative legal research is based on materials primary and secondary law, namely research that refers to the norms contained in the laws and regulations. ${ }^{16}$ Legal-normative research is a library research, which is a research on secondary data including private documents, books, and official documents issued by the government. The normative approach emphasized juridical issues regarding the legal rules on money laundering offense.

\section{RESULT AND DISCUSSION}

\section{Implementation of Principles of Identifying Service Users and Suspicious Financial Transaction for Profession Report Submission as an Effort to Prevent Money Laundering Offense in Various Countries}

The implementation of the principles of service useridentification stated in article 18 to 22 section 2 is one of the legal foundations of the implementation of the principle of service useridentification in the context of money laundering offense prevention. The articles are as follows: ${ }^{17}$

Article 18Act No. 8 of 2010 Regarding the Prevention and Eradication of Money laundering Offense states that:

14 Yudi Kristiana, 2015, Pemberantasan Tindak Pidana Pencucian Uang Perspektif Hukum Progresif, Thafa Media, Yogyakarta, page. 7-8

15 Amiruddin \& Zainal Asikin, Pengantar Metode Penelitian Hukum, 2012, Raja Grafindo Persada, Jakarta, page. 118

16 Soeryono Soekanto, Pengantar Penelitian Hukum, UI Press, Jakarta, page. 20

17 UU No. 8 Tahun 2010 Tetang Pencegahan dan Pemberantasan Tindak Pidana Pencucian Uang, Article 18-22 
a. Supervisory and regulatory institution establishes the regulatory principles regarding Service User

b. Informant must implement the principles of Service User Identification stipulated by every supervisory and regulatory institution as stated in clause (1)

c. The obligation to implement the principles of Service User identificationas stated in clause (2) is carried out when:

1) Runningbusiness relation with Service User;

2) Existing Financial Transaction in Rupiah and/or foreign currency with the value of more than or equals to IDR 100.000.000.,00 (one hundred million rupiah);

3) ExistingSuspicious Financial Transaction related to Money laundering offense and terrorism funding offense or

4) The informant questions the validity of the information reported by Service User

d. Supervisory and Regulatory Institution is required to conduct supervision on the informant compliant in implementing the principles of Service User Identification.

e. The principles of Service User Identificationmust at least include:

1) Service User Identification;

2) Service User Verification; and

3) Service User's Transaction Monitoring.

f. In terms of unavalaibility of Supervisory and Regulatory Institution, the stipulation regarding the principles of Service User identificationand its supervision is regulated by the Head of Financial Transaction Analysis and Reporting Center (PPATK) regulation.

Article 19 Act No. 8 of 2010 Regarding the Prevention and Eradication of Money Laundering Offense stipulates that:

a. Every individual performing the Transaction with the informant must provide valid identity and information required by the Informant and include at least self-identification, source of fund, and the purpose of the Transaction by completing the form provided by the informant and attaching the Supporting Documents.

b. In terms of transaction performed for another party's interest, Each Individual as mentioned in clause (1) must provide information regarding self-identification, source of fund, and the purpose of transaction of said party.

Article 20 Act No. 8 of 2010 regarding the Prevention and Eradication of Money Laundering Offense stipulates that:

a. Informant must be noticed that the Service User carrying out Transaction with the Informant is acting on their own behalf or on behalf of another party.

b. In terms oftransaction with the Informant is carried out on anindividual's own behalf or on behalf of another individual, the 
Informant must request information regarding the identity and the Supporting Documents from the Service User and the saidindividual.

c. In terms ofincomplete identity and/or Supporting Documentsprovided as mentioned in clause (2), the Informant must decline the Transaction with said individual.

Article 21 Act No. 8 of 2010 regarding the Prevention and Eradication of Money Laundering Offense stipulates that:

a. The Identity and Supporting Documents requested by the Informant must correspond to the regulatory laws established by every Supervisory and Regulatory Institution.

b. Informant must keep the record and Documents regarding the identity of Transactor at least 5 (five) years since the end of the business relationwith said Service User.

c. Informant who does not fulfill the obligations as mentioned in clause (2) will be given penalty in accordance with the regulatory laws.

Article 22 Act No. 8 of 2010 regarding the Prevention and Eradication of Money Laundering Offense stipulates that:

a. The Provider of Financial Service as stated in Article 17 clause (1) letter a must terminate all business relation with the service provider if:

1) The Service User refuses to comply to the principle of Service User identification; or

2) Financial Service Provider questions the validity of the information provided by the service user.

b. Financial Service Provider as stated in article (1) must report to PPATK regarding the said business relation termination as Suspicious Financial Transaction

From the aforementioned articles, it can be concluded that:

Article 20 clause (1) and (2), based on the phrase "acting on their own behalf or on behalf of other individual," implies that the Service User runningbusiness with the Informant may not be the owner of all or a portion of the money to be transacted by said Service User. It means that there is a potential that the Service User uses other people's name so that the Service User who owns the transacted money can falsify their identity, so that if the transaction is suspected by the informant, the service user can avoid any prosecutions.

Article 21 clause (3) exists as an anticipation so that the informant itself does not perform money laundering, or deliberately allows money laundering to occur. In the context of Money laundering offense, advocate, notary, land titles registrar, accountant, public accountant, financial planner professions are assigned as informants.

The urgency of said professions being assigned as informants includes:

a. Based on the typology and motives of money laundering, it is known that said professions are susceptible to being taken advantage of by money launderingperpetrators in hiding or dissimulating the origin or 
source of funds of the wealth obtained from crimes as stated in article 2 of the Act No. 8 of 2010 regarding the Prevention and Eradication of Money Laundering Offense;

b. To strengthen anti-money laundering and terrorism funding regime in Indonesia such as Financial Service Provider (PJK) and other Goods and/or Service Provider (PBJ), through their role as the front line in identifying and reporting suspicious financial transaction to PPATK; and

c. To equip said professions with the implementation of anti-money laundering and terrorism funding program which has become international standard in accordance with the Financial Action Task Force (FATF) recommendation. ${ }^{18}$

Article 18 clause (2) of the Act No. 8 of 2010 regarding the Prevention and Eradication of Money Laundering Offense states that Informant must implement the Principles of Service UserIdentification (PMPJ) stipulated by each supervisory and regulatory institution. Said PMPJ are assigned by the Supervisory and Regulatory Institution as regulated in article 18 clause (2) of the Act No. 8 of 2010 regarding the Prevention and Eradication of Money Laundering Offense such as the following:

a. Advocate, assigned by PPATK;

b. Notary, assigned by The Ministry of Law and Human Rights;

c. Land Titles Registrar, assigned byPPATK;

d. Accountant and Public Accountant, Assigned by The Ministry of Finance, and

e. Financial Planner, assigned by PPATK. ${ }^{19}$

Professional obligations as regulated in article 8 clause (1) Government Regulation No. 43 of 2015 regarding Informant in the Prevention and Eradication of Money Laundering Offense are as follows:

a. Informant as referred in article 3 must submit report on Suspicious Financial Transaction towards PPATK in the interest of or for and on behalf of Service User, regarding:

1) Purchase and selling of Property;

2) Management of money, stock, and/or other financial service product;

3) Management of giro account, saving account, deposit account, and/or stock account;

4) Operation and management of company; and/or

5) Establishment, purchase, and selling of legal entity.

b. The stipulation as stated in clause (1) is exempted for advocates acting on the interest of or for and on behalf of Service User with the purpose of;
1) Ascertaining service user's legal position, and

18 Surat Edaran Nomor 02 Tahun 2019, Tentang: Pedoman Penerapan Prinsip Mengenali Pengguna Jasa Dan Penyampaian Laporan Transaksi Keuangan Mencurigakan Bagi Profesi, I. Umum 19 Ibid 
2) Handling case, arbitration, or dispute settlement alternative.

From article 8 clause (1) and (2), we can conclude that informant must submit report on Suspicious Financial Transaction (LTKM) to PPATK

The benefit of the professional obligation as stated above towards the effort of preventing and eradicating money laundering offense and terrorism funding is that professionals, along with other informants, act as a goal keeper of anti-money laundering and terrorism funding regime in Indonesia, which will optimize the process of identification and reporting on perpetrators of money laundering offense and terrorism funding in Indonesia. Through the implementation of PMPJ obligations and submission of LTKM to PPATK, the gap that can be exploited by TPPU perpetrator is minimized because there is no longer regulatory arbitrage in the effort to prevent and eradicate TPPU and Terrorism Funding Crime (TPPT) in Indonesia.

a. Article 18 Act No. 8 of 2010 regarding the Prevention and Eradication of Money Laundering Offense stipulates that the PMPJ must at least include:

1) Service user identification;

2) Service user verification; dan

3) Service user monitoring

b. Article 1 No. 12 Act No. 8 of 2010 regarding the Prevention and Eradication of Money Laundering Offense defines service user as the party using the Informant's service, which is also known as client, customer or the party carrying out business relations with the informant.

c. The identification process is done by collecting service user's information and documents. Through the identification process, the profile of the service user carrying out business relation with professional is known, which can be used as the basis of the monitoring process. For instance, the process of identification in notary is by collecting information from the service user, as an example, the identity of an individual service user includes full name, identification Number, place and date of birth, nationality, and other information in accordance with the regulation.

d. The verification process is done in order to inspect the information and document provided by service user, and may involve requesting additional information through face-to-face meeting with the service user.

e. The monitoring process is conducted in order to determine the consistency between the transaction and the service user's profile. For instance, the monitoring process done by Accountant and Public Accountant involves observing the method of cash and non-cash bank transaction payments, the transactor, the normal transaction, and/or the date of transactions. 


\section{Factors of Stimulating the Occurrence of Money Laundering Offense in Various Countries}

There are 9 factors stimulating the occurrence of Money Laundering Offense in various countries, namely ${ }^{20}$ :

a. Globalization;

In this context, globalization does allow Money Laundering perpetrator to utilize international financial system and banking to carry out their actions.

b. Technological Advancement:

The most prominent factor stimulating Money Laundering is information technology, that is, the emergence of internet with its incredibly rapid advancement. With the advancement of information technology, the borders between countries become meaningless, and the world becomes one borderless unity. As a result, organized crimes operated by criminal organizations can be carried out beyond borders easily. Nowadays criminal organizations can easily and quickly move large sum of money from one jurisdiction to another. For example, by using Automatic Teller Machines (ATM), criminals are able to transfer funds to US accounts from other countries and in an instantwithdraw the fund from ATM around the world without revealing their identity.

c. Bank's strict Secrecy Policy;

In relation to tax reform, Finance Ministers of European Union countries and the UK hold a summit conference. The Ministers of Financesee eye to eye to removethe banks' strict secrecy policy. According to the UK delegate, if the European Union is serious in combating Tax Evasion, they must consider the removal of bank secrecy policy. Act No. 10 of 1998 regarding the Principles of Banking Regulations, specifically regulating bank's secrecy is stated in article 40 as follows: Clause 1:

Banks are obliged to maintain secrecy regarding customers and their savings, except in the cases referred in article 41 , article 41 a, article 42, article 43, article 44, and article 44a. Clause 2:

parties.

The stipulation referred in clause 1 also applies to the affiliated

This secrecy is normative in the form of positive law that is mandatory in nature. This mandatory is implied in the word "obliged" in article 40 clause 1 Act No. 10 of 1998 as mentioned before. The basis for bank's obligation in this case is the act or positive law. Violation towards this secrecy policy is not only a Civil Violation, but is considered Criminal Violation as well.

20 Sultan Remi Sjahdeini, Pencucian Uang: Pengertian Sejarah, Faktor-Faktor Penyebab, dan Dampaknya Bagi Masyarakat, Jurnal Hukum Bisnis, Volume 22-Nomor 3, 2004, page 12-17. 
These types of policyarecommonly exploited by Money Laundering perpetrators very well. Thanks to such secrecy policy, banks can not only accumulate legal funds from people, but also illegal ones from anyone including big corporations or government officials involved in the aforementioned Money Laundering practice.

d. The possibility of using alias or anonymous:

For instance, in Austria, one of the countries used as a base for a number of Money Laundering practicescarried out by corruptors and organizations engaged in narcotics trades allows an individual or organization to open an account anonymously.

e. The emergence of Electronic Money (E-Money):

Money laundering carried out using the internet network or cyberspace is commonly known as cyberlaundering. E-Money products havemainly been developed to allowtrades through Open Computer Network instead of Face-to-Face trades.Such systems provide goods and services through the internet which will later be utilized by cyberlaunderers. Some observers predict that the increase of E-Commerce done through the network will stimulate the growth of E-Money. E-Money is the generic name given to the concept of money digitally signed by an issuing institution through private encryption keys and transferred to an individual. The money can then be negotiated electronically with other parties as a payment for goods or services from around the world.

f. The possibility of layering practice:

Layering can be a factor allowing Money Laundering to be rampant, because by performing layering, the deposant in bank may not be the true owner of the funds. The deposant only acts as a trustee for another party who entrusts them to deposit a sum of money into a bank. Oftentimes, the party entrusting the money is not the real owner of the fund either, as they may acts as a trustee for the true owner. In other words, the depositor does not know the true owner of the fund either, because they only act as a trustee for the true owner. Moreover, the trustee may act for another trustee acting for another trustee and so on before arriving to the true owner. There is a relay of entrustments for several layers which makes it difficult for Law Enforcement to detect Money Laundering.

g. The Confidentiality of the Relationship between Lawyer and client and between Accountant and Client:

Savings funds in various banks are often registered under the name of a certain attorney office, while the relationship between client and lawyer is protected by law. For this reason, lawyer who saves funds in a bank on behalf of the Client cannot be forced by the authority to reveal the identity of the Client.

h. The Government's Unseriousness in Eradicating Money Laundering Practices: 
This is because the concerned government does knowingly allow Money Laundering practices to occur because the government is benefitted when the aforementioned illegal money is saved in a financial institution in the country. The profit from the funds amassed in banking institutions may be needed to fund the country's development, or that the fund allows banks to receive a lot of profit because further distribution of those funds contributes large amount of tax to the country.

i. The Lack of Money Laundering Criminalization

In some countries, the lack of regulations regarding Money Laundering in its criminal law system allows money laundering practices to thrive. The absence of regulation regarding the eradication of money laundering offenses in said country is usually caused by the government's unwillingness to seriously eradicate Money Laundering practices. As we know, Indonesia, for instance has only established regulations regarding money laundering offense in 2010. Therefore, it is unsurprising that Indonesia is considered heaven by money launderers.

\section{CONCLUSION}

Theresult of this research from discussion inabove, the implementation of the principles inidentifying service users regarding the prevention and eradication of moneylaundering offense is identifying service users while having a businessrelationship involving suspicious financial transactions related to moneylaundering offense. The informant questions the validity of information provided by theservice user, which necessitates the implementation of the principle ofidentifying the service user in carrying out banking transactions. The factorspromoting the occurrence of money laundering offense in various countriesconsist of 9 aspects, namely: globalization, technological advancement, banks' strict secrecy policy, the possibility of saving using an alias or anonymous, the emergence of electronic money, the possibilityof layering practice, the confidentiality of lawyer-client andaccountant-client relationships, the government unseriousness in eradicatingmoney laundering offense and the lack of money laundering criminalization.

\section{BIBLIOGRAPHY}

\section{Books:}

Arief Amrullah. 2004. Tindak Pidana pencucian uang (Money Laundering), Bayumedia Publising, Malang;

. 2020. Tindak Pidana Pencucian Uang dalam Perspektif Kejahatan Terorganisasi Pencegahan dan Pemberantasannya, Kencana, Jakarta;

N.H.T Siahaan. 2008. Money Laundering \& Kejahatan Perbankan, Jala permata, Jakarta; 
Sultan Remy Sjahdeini, 2004, Seluk-beluk Tindak Pidana Pencucian Uang dan Pembiayaan Terorisme, Pustaka Utama Grafiti, Jakarta;

US Geverment. 2000. Secreataryof the Treasury dan Attorney General, TheNational Money Laundering Strategi;

Yudi Kristiana. 2015. Pemberantasan Tindak Pidana Pencucian Uang Perspektif Hukum Progresif. Thafa Media. Yogyakarta;

\section{Journals :}

Budi Bahreisy, Implementasi Undang-Undang Tindak Pidana Pencucian Uang Terhadap Kerugian, Legislasi Indonesia Journal, Volume 15, Number 2, July 2018;

Febrina Annisa, Prima Resi Putri, Penerapan Program Apu Ppt Untuk Mencegah Pencucian Uang Dan Pendanaan Terorisme Pada Industri Fintech, Adil Journal, Volume 11 Number 2, 2020;

Gandhung Wahyu, F.., Joko Supriyanto, Urgensi Penanggulangan Tindak Pidana Pencucian Uang Pasa Kasus Korupsi, Recidive Journal, Volume 3, Number 3, September - December 2014;

Herlina Hanum Harahap, Pencegahan dan Pemberantasan Tindak Pidana Pencucian Uang, Amaliah Journal, Volume 4 Number 2, November 2020;

Ida Musofiana, Anti-Corruption Education at an Early Age as a Strategic Move to Prevent Corruption in Indonesia, Proceeding The 2nd Proceeding 305, Indonesia Clean of Corruption in 2020, December 201;

Khairul, Mahmul Siregar, Marlina, Kewenangan PPATK Dalam Pencegahan dan Pemberantasan Tindak Pidana Pencucian Uang, Mercatoria, Volume 4 Number 1, 2011;

M. Arief Amrullah, Pencegahan Tindak Pidana Pencucian Uang Melalui Jasa Gatekeeper di Indonesia, Cakrawala Hukum Journal, Volume 6, Number 1, Juni 2015;

\section{Legislations :}

Undang-Undang Nomor 8 Tahun 2010 tentang Pencegahan dan Pemberantasan Tindak Pidana Pencucian Uang.

Surat Edaran Nomor 02 Tahun 2019 tentang Pedoman Penerapan Prinsip Mengenali Pengguna Jasa dan Penyampaian Laporan Transaksi Keuangan Mencurigakan Bagi Profesi. 